Available online:

DOI: http://dx.doi.org/10.24865/ajas.v6i1.313

\title{
AN ANALYSIS OF TERM SARIYYAH IN THE TRANSLATION OF THE BOOK TITLED NURUL YAQIN FI SIRAH SAYYIDIL MURSALIN (2010) BY SHEIKH MUHAMMAD AL-KHUDHARIY
}

\author{
Namira Fauzia Syahrefi, Abdul Muta'ali \\ Universitas Indonesia, Depok, Indonesia \\ Corresponding E-mail : namira.fauziaas@gmail.com
}

\begin{abstract}
This paper presents the analysis of the translation of the term sariyyah in the book "Nurul Yaqin Fi Sirah Sayyidil Mursalin" by Sheikh Muhammad Al-Khudhari. The translator of this book does not translate the term sariyyah. This translating process is called foreignization, the opposite of localization. The data was taken from the book "Nurul Yaqin Fi Sirah Sayyidil Mursalin" by Sheikh Muhammad Al-Khudhari which was published by Dar El Hadits, Cairo in 2010, with a total of 270 pages and its Indonesian translation book entitled "Nurul Yaqin Sirah Nabi Muhamad Pemimpin Para Rasul" (Nurul Yaqin The Biography of Muhammad PBUH, Leader of the Apostles). The word sariyyah is repeated 45 times in the Arabic book and 46 times in the Indonesian translated book. The researcher used the descriptive analysis method with the Peter New Mark translation procedure approach using the $V$ diagram translation theory. The analysis results prove that the word sariyyah is not translated because the translator is doubtful about the appropriate sariyyah word matching in Indonesian.
\end{abstract}

Keywords: translation, Arabic-Indonesian, Prophet Muhammad, History of Islam

\begin{abstract}
Abstrak
Makalah ini memaparkan hasil analisis terjemahan kata sariyyah dalam kitab Nurul Yaqin Fi Sirah Sayyidil Mursalin karya Syeikh Muhammad Al-Khudhari. Penulis dalam buku ini tidak menerjemahkan kata sariyyah yang dalam prosedur terjemahan hal ini disebut dengan foreignization. Data penelitian makalah ini diambil dari kitab Nurul Yaqin Fi Sirah Sayyidil Mursalin karya syeikh Muhammad Al-Khudhari, yang terbit tahun 2010, berjumlah 270 halaman, dan diterbitkan oleh Dar El Hadits, Kairo serta buku terjemahan Bahasa Indonesia dari buku ini yang berjudul "Nurul Yaqin Sirah Nabi Muhamad Pemimpin Para Rasul". Kata sariyyah dalam buku sumber berbahasa Arab terulang sebanyak 45 kali serta terulang 46 kali dalam buku terjemahan berbahasa Indonesia. Metode yang digunakan adalah metode deskriptif analisis dengan pendekatan prosedur penerjemahan Peter New Mark yang menggunakan teori penerjemahan diagram-v. Hasil analsis membuktikan bahwa kata sariyyah tidak diterjemahkan karena penerjemah belum mengetahui padanan kata sariyyah yang sesuai dalam bahasa Indonesia dibuktikan dengan diterjemahkan dan tidakditerjemahkannya kata sariyyah meskipun dalam satu topik besar yang sama dan telah ada arti makna kata sariyyah dalam kamus Arab-Indonesia.
\end{abstract}

Kata Kunci: terjemahan, Arab-Indonesia, Nabi Muhammad SAW, Sejarah Islam 


\section{Arabi : Journal of Arabic Studies}

\section{Introduction}

Many Arabic language books are translated into the Indonesian language for various purposes like Islamic sources, education, or literature. Islamic source books are still the most books translated from Arabic to Indonesian because Islam was revealed in the Middle East in the Arabic language. Arabic-Indonesian translation was done directly from Arab to Indonesia like "Khudz 'Aqidatak" by Sheikh Muhammad bin Jamil Zainu was translated into Indonesian "Ambil Akidahmu" (Take Your Aqeeda). Alternatively, some translations are Arabic to English, then they are translated to Indonesian, for example," Imra' ah 'inda Nuqtah al-Sifr" by Nawal El Sa'adawy, which translated to "Perempuan di Titik Nol" from the English book "Woman at Point Zero." The primary Islamic source, Qur'an, is claimed to have the best quality translation because it is the holy book of Muslims, and its translation process was done after some years (Syihabuddin, 2016). The book titled "Nurul Yaqin Fi Sirah Sayyidil Mursalin" which was translated to "Nurul Yaqin Sirah Nabi Muhammad Pemimpin Para Rasul" (Nurul Yaqin The Biography of Muhammad PBUH, Leader of the Apostles) in Indonesian is an Islamic history book specific in the life of Prophet Muhammad PBUH in spreading Islam to Arabic people in those days. The book was translated directly from Arabic into Indonesian.

A translation cannot be judged as right or wrong because it depends on the knowledge translators have about the topic and the language skill, either the source language or the target language. Based on research, there were some errors or miss-matching words in some Arabic translated books that lead to misconception in readers, especially commoners. In Indonesia, translated books had a gap between books with good quality and less good quality translation. Hence scientific researches are needed to find empirical evidence that can help with the less good quality translation. Problems occur in Arabic-Indonesian translation because (a) the Translation process itself is challenging, (b) there are substantial differences between Arabic and Indonesian language, (c) translators are having less knowledge about the target language, which lead to interference case, and (d) translators are having less knowledge about translation theories (Syihabuddin, 2016).

In some Indonesian translations of Arabic books, some translation mistakes or inaccuracies on equivalent words in Indonesian lead to misunderstandings by the reader, especially commoners. Two of them are: (1) Mistakes on connotation, for example,

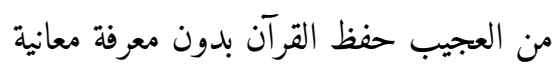

\section{/manil 'ajīb hafadzal qur'ān bidūni ma'rifati ma'āniyah/}

The clause can be translated mistakenly as 'luar biasa ada orang yang bisa menghafal AlQur'an tanpa mengetahui maknanya' (Amazingly, ones can memorize the Qur'an without knowing its meaning), which will be understood as a negative connotation because memorizing Qur'an without knowing its meaning is not worth the praise. In the opposite, if the translation is done correctly, the meaning will be: 'aneh sekali ada orang yang menghafal Al-Qur'an tanpa mengetahui maknanya' (It is weird that one memorized the Qur'an without knowing its meaning) (Hidayatullah, 2017). The readers will understand this translation as a positive connotation because the clause was consistent with their understanding that the Qur'an contains Islamic teachings that are mandatory to obeyed, so people who memorized it must also be obedient that has understood its message.

(2) Mistakes that were caused by carelessness and stiffness. For example

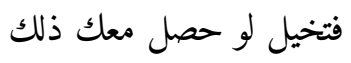

\section{|fatakhayyal law ḥasala ma'aka ẑalik/}

The word تخيل/takhayyal/ sometime was skipped and the translation was directly translates the word حصل / hashalal 'berhasil' (succeed). Thus, the right translation is 'karenanya bayangkan jika itu terjadi padamu' (Hidayatullah, 2017). 
Translating is a process of transferring as many words as possible from the source language (SL) to the translation language (TL). Hence, readers in translation language understand $\mathrm{s}$ the message of the text. According to Mounin in Newmark (1988) translation process is not easy to be done moreover to be an authentic result as the translator's job is to translate, not to make. This statement does not mean that a translation should follow every source language's linguistic formula. Newmark, in his book "A Textbook of Translation," gives three options regarding translation, namely (1) if using literal language can be more understandable by the reader, the translation should be apt to the source language (SL), (2) the SL does not have to be used if its linguistic formula is less concerned and (3) pay less concern in SL's language formula feasibility, but the nearer translation to the linguistic formula, the better. In addition, criteria adjustment is needed in the translating process (New Mark, 1988) by knowing the purpose desired to be delivered. These purposes are divided into a translation as a science done by literal translating, translation as a craft done by context adaptation, translation as an art done by sentences reformulation to reach the aesthetic element, and translation as a taste, the highest criteria in the translating process which is done by subjective translating.

The Indonesian translation of the book Nurul Yaqin fi Sirah Sayyidil Mursalin is an easyunderstand book because it is written using simple language, and at the same time does not reduce the message that will be delivered in the source language. Despite all of the content, it was found that one word was not translated from the beginning until the end of the book. Language development, with no doubt, also affects the translating process. The process of un-translating a word without knowing the reason behind it probably allows people who want to abuse the meaning by interpreting subjectively (in this context) for fighting against Islam (anti-Islam). The misuse of translating has happened in the translation process of the word kafir in the Al-Quran with Indonesian translation (Muta'ali, 2018), the dilemma in removing the word kafir in society (Nahdlatul Ulama, 2019) and mut'ah (contract) wedding culture which was a trending topic in 2018. The book is distributed among commoners who do not have professional knowledge in Islamic religious study to differentiate the right and wrongs; thus, the anticipation of misinterpretation and wrong delivered message must have done. As an Indonesian student majoring in Arabic studies, the writer researched the corpus with the primary goal to conclude reasons behind the not translated word, sariyyah in the Indonesian translation book using applied linguistic science and the translation theory in analyzing the data.

This research background is the needs of Islamic religious sources among Indonesian people. These days, there is an increase in the number of interest in learning Islamic religious studies, especially among Muslims who are the majority by the number of 204.807 .000 people (BPS, 2010). Despite the secular life of the muslim (Mujani and Liddle, 2009) learning Islam is part of it. Hence, the sources supporting the learning process are needed, including translated books in high quality in order to make sure knowledge gained by the reader in concordance with the Qur'an, sunna, and ijma' (agreement of the scholars). In this research in which the corpus data is the word sariyyah in the book entitled "Nurul Yaqin fi Sirah Sayyidil Mursalin" in Arabic and its translation in Indonesian, "Nurul Yaqin Sirah Nabi Muhammad Pemimpin Para Rasul" which was translated by Muhammad Faisal Fahli, the researcher analyzed the translation process done by the translator.

Dewi Laraswaty had done researches on the same topic on Indonesian translation using foreignization theory in An Analysis of Domestication and Foreignization of Cultural Words Translation in Andrea Hirata's Novel Entitled "LASKAR PELANGI" (2014), which discuss non translated words that describe Belitung's culture in the English edition book. The V diagram theory by Peter Newmark was used in the research entitled Translation Method, and Meaning Equivalence in The Song Let It Go Sung By Demi Lovato and Lepaskan Sung By The Artists (2016) by Maryati, which analyze the type of translation that used according to levels of translation in the V diagram. However, this research discussed the connection between the word 


\section{Arabi : Journal of Arabic Studies}

sariyyah, which is not translated into Indonesian and Indonesian military terms. The research can be summarized as follow. Research problems:

1. How the word sariyyah is described.

2. How was the translation process done.

3. What is the translator's reason for not translating the word: sariyyah.

The researcher held this research because it was found that all of the word sariyyah in this book was not translated and was written as the original text except for some pages, namely page 157 in which the word was written into 'sariyyah (Ekspedisi),' page 161 in which the word sariyyah was translated into 'personel kaum muslimin' (personnel of Muslims), page 260 in which the word sariyyah was translated into 'pasukan bin Maslamah' (troops of Muhammad bin Maslamah), and page 268 in which the word sariyyah was translated into 'pasukan kaum muslimin' (troops of Muslims). This research aimed to found the reason behind the not translated word, sariyyah into Indonesian, and to identify the translation method and process. At the end of the paper some suggestions regarding the accurate translation of the word sariyyah are provided.

The theory used in this study was a translation theory by Lawrence Venuti (1995), domestication and foreignization. Venuti is an American professional translator from Italy. He focused on historical texts, movies, and artworks translation. Domestication and foreignization theory explain the option that can be chosen by the translator, which is introducing a new culture to the reader or siding with readers. In order to ease the reader to understand the translation outcome, foreignization usually choose. This theory is used based on the translated text adjustment, whether it is more understandable to the reader if it uses the source language or the target language, especially when viewed from a cultural perspective. Venuti criticizes translators who use domestication in the translation process (translating a word into the target language), resulting in eliminating cultural values from the target language. He emphasized that maintaining a foreign language in translation is more necessary if it makes cultural elements conveyable.

\section{Foreignization}

The foreignization translation process is done when the translator does not translate a word and leaves it written originally as the source language. Translation done with this theory is subjective because the translator leaves the writer's ideas as they are not considering the culture (Venuti, 1995: 24). The translator is not seen and ignored in the translation process with this theory. Therefore, Venuti wrote it in his book Translator Invisibility (1995). It is also the same as the other theories in the same book: that the translator is invisible and does not seem to have the right to a translation process (Myskja, 2013). Foreignization is selecting foreign texts and developing translation methods that do not follow the dominant cultural value of the target languages. For further comprehension, the translation of cultural text is also in relation also with Venuti's theory that is known as "untranslatability" (Baer, 2020).

\section{V diagram}

This study also uses a translation method approach, which is the method by Peter New Mark that chosen in translating text with adjustments based on the type of the SL text. He said that the fundamental concept of the aim of translating is "to produce as nearly as possible the same effect on the readers as was produced on the readers of the original (Callow and Callow, 1982). Meanwhile in his book, "A Textbook of Translation" (1988), Peter Newmark reveals that translation discussions always discuss whether a translation was done literally or freely. These options of translation led to ideas for the methods offered to be used in the translation process. Through the V Diagram, Newmark emphasizes the idea of a translation process method into two parts, namely based on the emphasis on SL (source language / SL) and TL (translation language / TL), which can be described as follows 


\author{
SL emphasis \\ Word-for-word translation \\ Literal translation Faithful \\ translation Semantic \\ translation
}

\author{
TL emphasis \\ Adaptation \\ Free translation \\ Idiomatic translation \\ Communicative translation
}

\section{Image 1. Newmark's V diagram}

a. Word-for-word translation is a translation method in which SL is higher than TL so that the semantics order of sentences adjusts the SL, and the words are translated one by one without considering the context. This translation is usually done on cultural texts to introduce the culture. This method can also be used in the pre-translation.

b. Literal translation is similar to the word for word method in which both are still translating word by word, but the grammatical structure of the sentence is adjusted to the one closest to SL.

c. Faithful translation is a translation that is based on mutual trust. The translator reproduced the source text contextual meaning yet used the source language word concerning the cultural field. This translation is done by fully entrusting the intention of the author of the source text.

d. Semantic translation considers the aesthetic and comfort aspects of the reader. Words in the cultural field can be translated using a TL word that has the closest meaning. This translation method is more flexible than the faithful translation.

e. Adaptation is a method that allows the translator to change the text into the context of the TL culture and even rewrite it. The adaptation method is used in the translation of drama, comedy, and poetry scripts.

f. Free translation allows the translator to translates without paying attention to linguistic rules, such as SL word order in the sentences and grammar.

g. Idiomatic Translation is the process of translating the text content by adding colloquial words and SL idioms that are not found in the source text.

h. Communicative Translation is used to produce a translation that is enjoyable to read contextually and linguistically.

\section{Method}

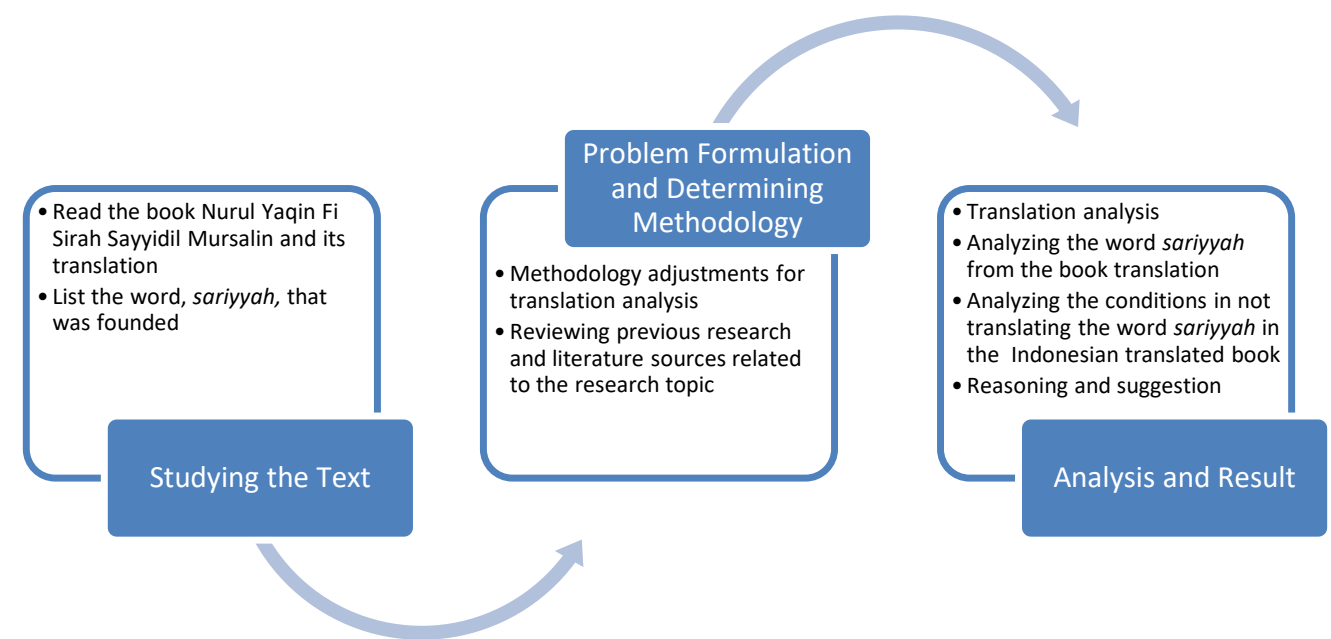

Picture 2. Research Process Flow

It is essential to use an approach and method in the research under the data studied. The researcher used a qualitative approach, a research procedure that produces descriptive data in the 


\section{Arabi : Journal of Arabic Studies}

form of words or verbally from people and observable behavior (Bogdan and Taylor in Moleong, 2004). The researcher also conducted literature studies on previous researches and books or journals on the topic studied. A literature study is also vital as it references the results or contributions given by the previous research and became the idea that motivates researchers to conduct research. A literature study is a systematic and reproductive method to identify and evaluate research that has been produced by researchers (Fink, 2005). This research can be also classified to be a case study research (Susam-Sarajeva, 2009).

The translation research method used is the translation process approach to determine the behavior, application, translation skills, and the relationship between cognitive abilities and translation results (Saldanha and O 'Brien, 2013). The translation process method was chosen because it is found in the data the use of a syntactic strategy in translating (Owji, 2013), namely the borrowing. It is a strategy to borrow words that belong to the source language to be written similarly in the translated text (Vinay and Darbelnet, 1958 in Saldanha O'Brien, 2013).

The data was taken from the Indonesian translation book entitled "Nurul Yaqin Sirah Nabi Muhammad Pemimpin Para Rasul" (Nurul Yaqin Sirah Nabi Muhammad Leader of the Apostles) refer to the original book, Nurul Yaqin Fi Sirah Sayyidil Mursalin.

The data analysis process that the researchers carried out was as follows:

1. Identifying and registering the number and position of sariyyah word distribution in Arabic books from the Nurul Yaqin Fi Sirah Sayyidil Mursalin

2. Comparing the word sariyyah in Arabic books and its translation in Indonesian books

3. Analysis using the $\mathrm{V}$ diagram

4. Presenting the findings (attached) in the form of an analysis table of the word sariyyah by dividing the column pages in the Indonesian translation book, the word sariyyah, or its position in the sentence, translating in the Indonesian translation book and analysis.

The writing of this journal is a combination of Indonesian and Arabic writing, along with its transliteration in Indonesian. In transliteration, the author refers to the Arabic-Latin Transliteration of the Joint Decree of the Minister of Religion and the Minister of Education and Culture of the Republic of Indonesia No. 158 the year of 1987 and No. 0543 / U / 1987.

\section{Analysis of Sariyyah word in the Indonesian Translation of the Book of Nurul Yaqin Fi Sirah Sayyidil Mursalin}

The word sariyyah in the Arabic dictionary of terms means part of an army of four to three hundred men or cavalry with a maximum number of 400 horses (Almaany, n.d.). The army is a vital institution owned by a country, or in the context of sirah nabawiyah (Prophet Biography), 'the story of the life of the Prophet' is the people. The function of the army is to maintain security and fight enemy attacks. The word sariyyah belongs to the singular noun class, while the plural is sariyyāt or sarāya . Sariyyah is a primitive noun, which is a unit noun. In Arabic, there are two types of nouns based on their relationship to the lexical root of a term/word (Ryding, 2005): isim jamid (primitive noun), a noun that is not the result of derivations/changes from other words and isim musytaq (derivative nouns), a noun which is formed from the derivation of a word (Holes, 2004). The isim al-wahdah (unit noun / collective noun) is a singular noun with a large number. Unit nouns are marked with the suffix $\ddot{\partial} / \mathrm{ta}^{\prime}$ marbuthah / either in feminine or masculine nouns (Ryding, 2005).

The translation of sariyyah to 'expedition' only translates sariyyah activities but has not explained the word sariyyah itself and the number of people who are members of sariyyah. However, the translator also translates sariyyah into 'troops of the Muslims' (because in the entire book, sariyyah consists of Muslims) or does not translate. The translator is inconsistent in translating the word sariyyah. In the Indonesian language, especially the Indonesian military term (Wandelt, 2009), troops were not found under a particular religion, let alone those sent before the 
war or not related to war. However, Muhammad Yunus's Arabic-Indonesian Dictionary lists the word sariyyah, which translates to 'sepasukan tentara' (army of soldiers).

\section{Foreignization and Faithful Translation Approaches to Translation Sariyyah Word}

In the process of translating the book of Nurul Yaqin fi Sirah Sayyidil Mursalin, by Shaykh Muhammad Al-Khudariy, the term سرية/sariyyah/ is not translated by the translator is a form of foreignization, remaining in the original form of the word according to the original text. Based on Peter Newmark the V Diagram, the process of translating this sariyyah word is faithful translation because the dominant translator does not translate the word sariyyah and writes it precisely as the word writing and pronunciation written in the original book and the source language. As a disclaimer the researcher reminding that the translation process is a subjective process which is very influenced by the translator. Translation can neutralize "a meaningful tension" (Folkart, p. 137 in Audet, 2009) present in the source text in the form of the connotations of register and level, and idiolexies and lexical creations (Audet, 2009).

The word sariyyah appears 45 times in Arabic sourcebooks and 46 times in Indonesian translated books. In the Indonesian translation book, there are two types of writing the word sariyyah, which are translated into different Indonesian phrases and are not translated, therefore the transliteration of the word sariyyah is written. The indefinite and definite words of /sariyyah/ that are not translated are 44, and 2 other sariyyah words are not written in Arabic books but written in Indonesian translated books or written in Arabic books but not translated in Indonesian translation books.

The following are definite form of sariyyah word which is translated into different words:

Table 1. Translation of the Definite Form of Sariyyah (as-sariyyah)

\begin{tabular}{|c|c|c|c|c|}
\hline \multirow[b]{2}{*}{ No. } & \multicolumn{2}{|c|}{ Page Number } & \multirow[b]{2}{*}{ Sentences in Arabic Book } & \multirow[b]{2}{*}{ The Translation } \\
\hline & $\begin{array}{c}\text { Arabic } \\
\text { Sourcebook }\end{array}$ & $\begin{array}{c}\text { Translated } \\
\text { Sourcebook }\end{array}$ & & \\
\hline 1. & 96 & 157 & 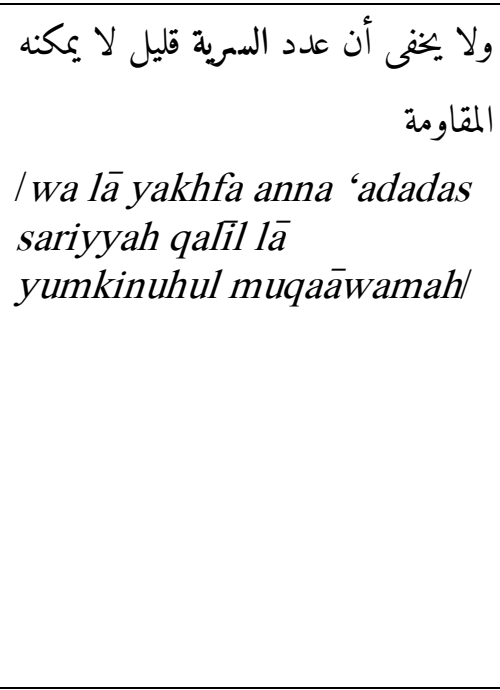 & $\begin{array}{l}\text { 'Alasan lainnya, } \\
\text { jumlah personel kaum } \\
\text { Muslimin yang } \\
\text { dikirimkan pada saat } \\
\text { itu sedikit dan tidak } \\
\text { akan mampu } \\
\text { mengadakan } \\
\text { perlawanan' (Another } \\
\text { reason was that the } \\
\text { number of Muslim } \\
\text { personnel sent at that } \\
\text { time was small and } \\
\text { would not be able to } \\
\text { resist). }\end{array}$ \\
\hline 2. & 119 & 202 & 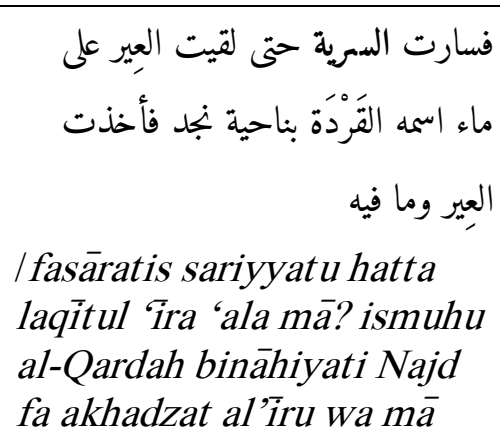 & $\begin{array}{l}\text { 'Pasukan muslimin } \\
\text { terus berjalan sampai } \\
\text { bertemu dengan } \\
\text { kafilah Quraisy di } \\
\text { suatu mata air yang } \\
\text { bernama Al-Qardah, } \\
\text { terletak di kawasan } \\
\text { Nejd.' } \\
\text { (The Muslim troops }\end{array}$ \\
\hline
\end{tabular}




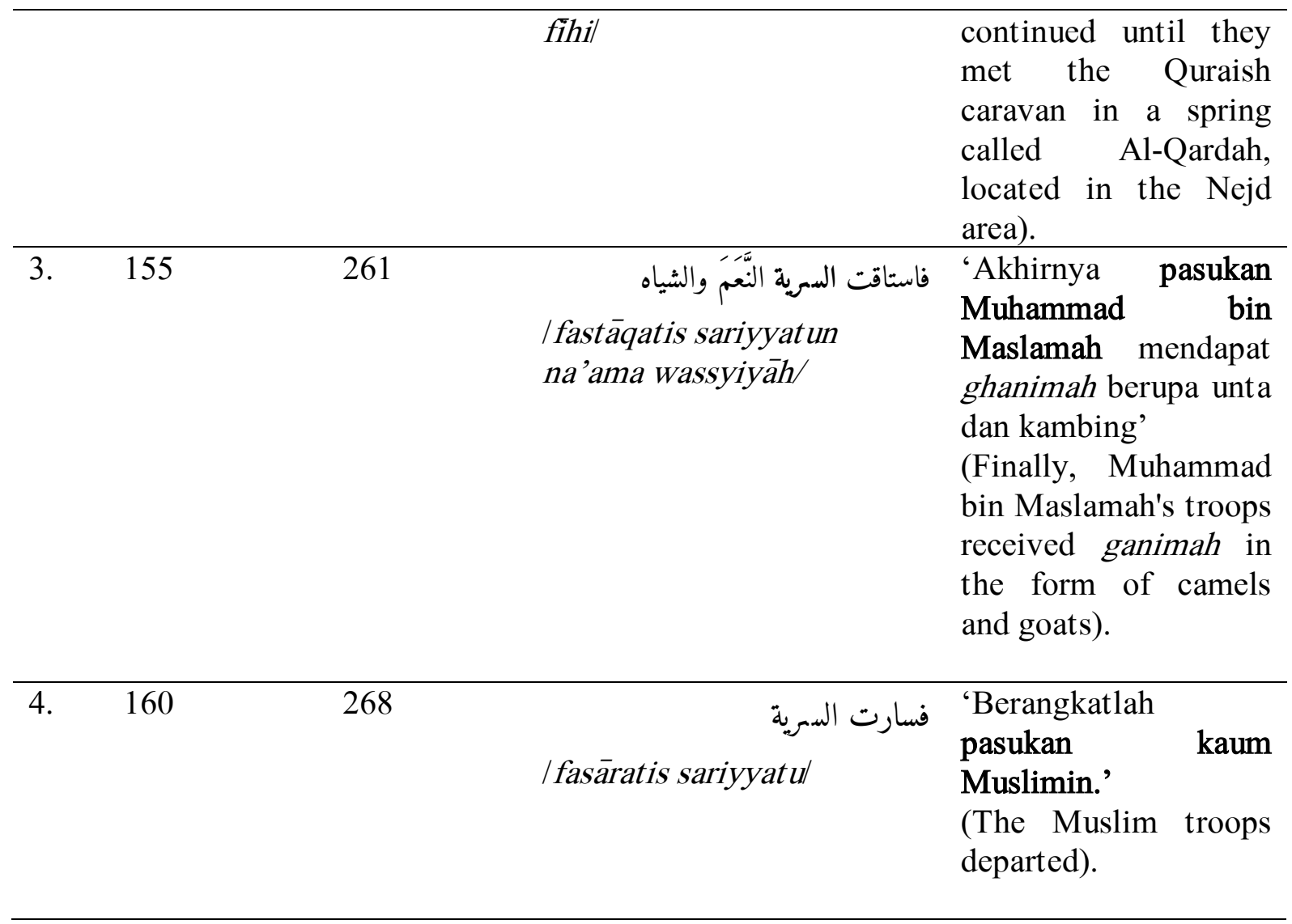

Meanwhile, the word sariyyah indefinite is found in the sentence or written as a subtitle. As one of the words in a sentence structure, the word sariyyah is not translated and dominantly written without another word. An example is on page 157 in an Indonesian language book, namely sentences

$$
\text { وفي رجب من هذه السنة أرسل سرية عدّتها ثمانية رجال }
$$

/ wa fì rajab min hadzihis sanah? rsala sariyyata 'addatahā tsamāniyyah rijālan /

which are translated to 'In the month of Rajab the (second) year Rasulullah PBUH sent a sariyyah whose personnel consisted of 8 people under the leadership of Abdullah bin Jahsy.' Meanwhile, in the Arabic sourcebook, the word sariyyah as subtitles was written without being followed or preceded by other words before sariyyah. In the translation book, the word sariyyah is not translated but written in different sentences. The table below presents examples of various sentence forms for translating the word sariyyah as subtitles that are translated.

Table 2. Translation of the Indefinite form of the word Sariyyah as a subtitles

\begin{tabular}{|c|c|c|c|}
\hline No. & $\begin{array}{c}\text { Translation } \\
\text { Sourcebook Page } \\
\text { Number }\end{array}$ & Translated Sentences & Sentence Forms \\
\hline 1. & 157 & $\begin{array}{l}\text { 'Sariyyah Zaid bin } \\
\text { Haritsah ke Wadil Qura } \\
\text { untuk Menyerang Bani } \\
\text { Fazarah.' } \\
\text { (Sariyyah Zaid bin } \\
\text { Haritsah went to Wadil } \\
\text { Qura to attack the Bani } \\
\text { Fazarah) }\end{array}$ & $\begin{array}{l}\text { Sariyyah <figure > ke } \\
<\text { place }>\text { untuk < activity>. }\end{array}$ \\
\hline
\end{tabular}


Arabi : Journal of Arabic Studies

\begin{tabular}{|c|c|c|c|}
\hline 2. & 157 & $\begin{array}{l}\text { 'Sariyyah (Ekspedisi) } \\
\text { Hamzah Bin Abdul } \\
\text { Mutthalib.' } \\
\text { (Sariyyah (Expedition) } \\
\text { Hamzah Bin Abdul } \\
\text { Mutthalib.' }\end{array}$ & $\begin{array}{l}\text { Sariyyah (Ekspedisi) } \\
\text { <figure>? }\end{array}$ \\
\hline 3. & 222 & $\begin{array}{l}\text { 'Sariyyah Muhammad bin } \\
\text { Maslamah ke Dhariyyah.' } \\
\text { (Sariyyah Muhammad bin } \\
\text { Maslamah to Dhariyyah) }\end{array}$ & $\begin{array}{l}\text { Sariyyah <figure> ke } \\
\text { <place>. }\end{array}$ \\
\hline 4. & 264 & $\begin{array}{l}\text { 'Sariyyah Ukasyah bin } \\
\text { Mihshan ke Bani Asad.' } \\
\text { (Sariyyah Ukasyah bin } \\
\text { Mihshan to Bani Asad) }\end{array}$ & $\begin{array}{l}\text { Sariyyah <figure> ke } \\
\text { <figure>. }\end{array}$ \\
\hline 5. & 265 & $\begin{array}{l}\text { 'Sariyyah Zaid bin } \\
\text { Haritsah ke Bani Sulaim } \\
\text { di Al-Jamum' } \\
\text { (Sariyyah Zaid bin } \\
\text { Haritsah to the Banu } \\
\text { Sulaim at Al-Jamum) } \\
\end{array}$ & $\begin{array}{l}\text { Sariyyah <figure > ke } \\
<\text { figure }>\text { di <place }>\text {. }\end{array}$ \\
\hline 6. & 266 & $\begin{array}{l}\text { 'Sariyyah Zaid bin } \\
\text { Haritsah Mencegat } \\
\text { Kafilah Quraisy yang } \\
\text { datang dari Syam.' } \\
\text { (Sariyyah Zaid bin } \\
\text { Harithah Intercepted the } \\
\text { Quraysh caravan that } \\
\text { came from Syria) }\end{array}$ & $\begin{array}{l}\text { Sariyyah <figure> } \\
\text { <activity>. }\end{array}$ \\
\hline 7. & 267 & $\begin{array}{l}\text { Sariyyah Zaid bin } \\
\text { Haritsah ke Tharf untuk } \\
\text { Menyerang Bani } \\
\text { Tsa'labah' } \\
\text { (Sariyyah Zaid bin } \\
\text { Harithah to Tharf to } \\
\text { Attack the Banu } \\
\text { Tsa'labah) }\end{array}$ & $\begin{array}{l}\text { Sariyyah <figure> ke } \\
\text { <place > untuk <activity>. }\end{array}$ \\
\hline 8. & 273 & $\begin{array}{l}\text { 'Sariyyah Amir bin } \\
\text { Umayyah Adh-Dhamri.' } \\
\text { (Sariyyah Amir bin } \\
\text { Umayyah Adh-Dhamiri) }\end{array}$ & Sariyyah <figure>. \\
\hline & 307 & $\begin{array}{l}\text { 'Sariyyah Basyir bin Sa'ad } \\
\text { untuk memerangi Bani } \\
\text { Murrah.' } \\
\text { (Sariyyah Basyir bin Sa'ad } \\
\text { to embattle the Banu } \\
\text { Murra) }\end{array}$ & $\begin{array}{l}\text { 'Sariyyah <figure> untuk } \\
\text { <activity>. }\end{array}$ \\
\hline 10 . & 312 & $\begin{array}{l}\text { 'Sariyyah Ghalib bin } \\
\text { Abdullah Al-Laitsi kepada } \\
\text { Bani al-Mulawwih di al- } \\
\text { Kadid.' }\end{array}$ & $\begin{array}{l}\text { Sariyyah <figure> kepada } \\
\text { <figure> di <place>. }\end{array}$ \\
\hline
\end{tabular}




\begin{tabular}{|c|c|c|}
\hline & $\begin{array}{l}\text { (Sariyyah Ghalib bin } \\
\text { Abdullah Al-Laitsi to the } \\
\text { Banu al-Mulawwih at al- } \\
\text { Kadid) }\end{array}$ & \\
\hline 11. 349 & $\begin{array}{l}\text { Sariyyah Qais bin Sa'ad } \\
\text { ke Sada' di Yaman.' } \\
\text { (Sariyyah Qais bin Sa'ad } \\
\text { to Sada' in Yemen) }\end{array}$ & $\begin{array}{l}\text { Sariyyah <figure> ke } \\
\text { <place> di <place>. }\end{array}$ \\
\hline 12. 350 & $\begin{array}{l}\text { 'Sariyyah Bisyr bin } \\
\text { Sufyan ke Bani Ka'ab dari } \\
\text { Khuza'ah.' } \\
\text { (Sariyyah Bisyr bin } \\
\text { Sufyan to Banu Ka'ab } \\
\text { from Khuza'ah) }\end{array}$ & $\begin{array}{l}\text { Sariyyah }<\text { figure }>\text { ke } \\
<\text { figure }>\text { dari < place }>\text {. }\end{array}$ \\
\hline
\end{tabular}

Meanwhile, there are also two sariyyah words in the Indonesian translation book that is not found in Arabic sourcebooks, namely on page 267 in the sentence "Apart from that this sariyyah Zaid captured a woman from among their ranks." and on page 308, which is a subtitle, namely Sariyyah Ghalib bin Ubaidillah Al-Laitsi to the people of Mifa'ah.

\section{The meaning of the word sariyyah in the book Nurul Yaqin Fi Sirah Sayyidil Mursalin}

In the Arabic sourcebook, the word sariyyah is written in two types according to Arabic grammar, which distinguishes into ma'rifat (definite) and nakirah (indefinite) forms (Baalbaki, 1995). Definites and indefinite only apply to nouns. According to the KBBI (the Big Dictionary of Indonesian Language), definite is 'tertentu' (certain) and indefinite is 'tidak pasti' (uncertain). In Arabic, the definite form of nouns is marked with the particle ال / alif lam / before a noun, while the indefinite noun form is ashl (root word) without particles (Hidayatullah, 2017). In the case of the word sariyyah the definite form of the word is السرية /assariyyah/ and the indefinite form is /sariyyah/. In the Arabic sourcebook, there are eight definite forms of sariyyah and 35 indefinite forms of sariyyah. In the definite form of the word sariyyah there is one of the eight untranslated words found on page 92 of the Nurul Yaqin fi Sirah Sayyidil Mursalin, namely the word assariyah, which located in the footnote section of the sentence

$$
\text { السرية قطعة من الجيش، ونريد بها كل غزاة لم يكن فيها رسول الله، والتى كان فيها تسمى غزوة }
$$

/Assariyyatu qit'ah minaljuyusy wa nuriidu bihaa kulli āazaah lam yakun fiihaa rasuulullahu wallataa kaanaa fiihaa tusamma à azwah /.

"Assariyatu adalah beberapa orang dari tentara, dan mereka diharapkan pada setiap perang yang tidak diikuti Rasulullah, saat keadaan bisa disebut perang."

(Assariyatu are some men in the army, and they are expected in every war that the Prophet did not participate when things can be called war).

Apart from these cases, five other cases of the definite form of sariyyah (السرية / assariyyah /) are also found in the Indonesian translation book with cases being translated or not translated. The list of pages that contain cases of the definite form of word sariyyah (السرية) / assariyyah/) in Arabic sourcebooks and Indonesian translation books are as follows:

1. On page 96, it is translated to 'personil kaum muslimin' (Muslim personnel)

2. On page 119, it is translated to 'pasukan muslimin' (Muslim troops)

3. On page 132, it is not translated

4. On page 133, it is not translated

5. On page 155, it translates to 'pasukan bin Maslamah (Muhammad bin Maslamah's troops) 
6. On page 159 , it is not translated

7. On page 160, it translates to 'pasukan kaum muslimin' (the troops of the Muslims)

In brief, from the definite form of sariyyah (السرية / assariyyah /) contained in Arabic books as well as in Indonesian translation books, there are three definite forms of sariyyah (السرية / assariyyah/) which are not translated and four definite sariyyah which are translated.

The definite for of sariyyah (السرية / assariyyah /) began to found on page 96 of the Arabic book -in the footnote section. The story on this page had entered the chapter of the first year of prophecy when Muhammad PBUH was sent to become an apostle. It can be seen that sariyyah began to exist when Muhammad PBUH had become an apostle. The group of people called sariyyah is a group which Muhammad PBUH ordered after he became a messenger.

Besides, on page 96, the definite form of sariyyah (السرية/assariyyah/) is written in the footnote as the description of the word:

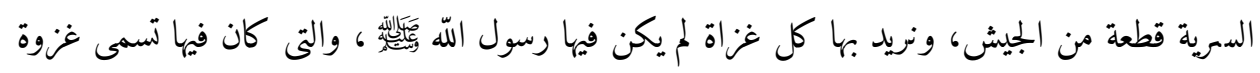

I Assariyyatu qith'ah minaljuyusy wa nurīdu bihā kulli gazah lam yakun fỉhā rasūlullahu wallatāa kānā fìhā tusamma gazwah/.

"Assariyatu adalah beberapa orang dari tentara, dan mereka diharapkan pada setiap perang yang tidak diikuti Rasulullah, saat keadaan bisa disebut perang."

(Assariyatu were some people of the troops, and they were expected to be in every war that Rasulullah was not on it when the situation can be called a war).

According to the researcher, the sariyyah description was written in the definite form of sariyyah (السرية/assariyyah/) because despite the function of the sentence as a descriptive sentence, there is no conjunction such as يعني/ya'nil 'is' or / هي /hiyal 'which is' (that referring to the word gender: feminine, singular).

The rest of the definite form of sariyyah (السرية /assariyyah/) was divided into two: translated in various phrases or was not translated. The translation into various phrases was done as a replacement for the Arabic article ال ال /al/ in the definite form of sariyyah (السرية/assariyyah/), which stands for 'that is' (as interpreted by the researcher) as well as the replacement for the word sariyyah. The phrases were taken from the story context in a particular part. They were written 'pasukan <nama tokoh>' (troops <a figure name>) or the phrase: 'personel kaum muslimin' (personnel of Muslims) or 'pasukan muslimin' (troops of Muslims). For the definite form sariyyah, which is not translated, it is divided into two: written as a definite form sariyyah or was written 'sariyyah <nama tokoh>' (sariyyah <a figure name>). In brief, the researcher identifies that the translator was doubtful in choosing the phrases or in choosing the type of translation (foreignization/domestication) used in translating the definite form of sariyyah (السرية/assariyyah/).

The opposite of the definite form is the indefinite form, سرية/sariyyah/. The definite form of sariyyah is dominantly written in the Arabic sourcebook. Most of it was written as the subchapter title, with two writing varieties: only سرية/sariyyah/without any word following and سرية >figure> or - >phrase>. Meanwhile, the rest of the indefinite form of sariyyah (سرية/sariyyah/) is part of a sentence. In the process of translating the indefinite form of sariyyah (سرية/sariyyah/) in the subchapter title, the dominant translation is sariyyah <figure> except for one translation form which is 'sariyyah (ekspedisi) < figure>'. The translation of the word sariyyah indefinite ( سرية/sariyyah/) in the section title becomes sariyyah <figure> was done even though the Arabic source only takes the form of the word سرية/sariyyah/without being preceded or followed by other words and the word 
- <frasa> (phrase). The indefinite form of sariyyah (سرية/sariyyah/) was written in an untranslated paragraph (written as sariyyah).

Unlike the Arabic sourcebook, which explains the meaning of the word sariyyah in a footnote, the Indonesian translation sourcebooks only use the word sariyyah without followed by the explanation even though it is a particular word that is unknown to ordinary people even though the first sariyyah word is written '(expedition)' after the word sariyyah. However, from all the words sariyyah found in the Indonesian translation book, it can be concluded that the word sariyyah always refers to a group of young people whose members are known to the Prophet Muhammad PBUH, with a maximum number of 10 people. They were ordered by the Prophet Muhammad PBUH to travel clandestinely against the opponents of Islam.

\section{The Indonesian equivalent of the word Sariyyah in the Military Field}

The Comprehensive Security Terms Dictionary (2009) is the only Indonesian military dictionary for the public that contains explanations of acronyms in the field. An English translation of the explanations as researchers from Germany created this dictionary. In the process of searching for the equivalent of the word sariyyah with Indonesian words, the writer looks for descriptions that are the same or close to the descriptions of sariyyah in the book Nurul Yaqin Fi Sirah Sayyidil Mursalin, which reads' Assariyyatu are some soldiers and they are expected in every war that the Prophet did not participate in when a state of war. '

By referring to the explanation of the word sariyyah in the Arabic sourcebook, sariyyah is 'some soldiers' and 'when a state can be called war.' With the keywords army and war, two acronyms are found in the comprehensive security dictionary, including OMP (Military Operation for War). Military War Operation, Military Operation for War, and OMSP (Military Operations Other Than War) Military Operations Other than War (MOOTW). If we look at the context of the story in the Arabic sourcebook, sariyyah refers to some people who were sent secretly before the war to spy on troops who were opponents of Muslim troops. Researchers believe that the word sariyyah in the context of the story and its explanation in Arabic sourcebook can be connected to soldiers who were assigned not during the war. The Indonesian equivalent can be used to translate the word sariyyah is Military Operations Apart from War (OMSP). The acronym OMSP also does not contradict the meaning of the word sariyyah in the Arabic-Indonesian Dictionary by Muhammad Yunus.

\section{Conclusion}

Research on the Indonesian translation of the book Nurul Yaqin fi Sirah Sayyidil Mursalin was carried out because the translator found the word sariyyah, which was not translated. The finding of definite and indefinite words sariyyah and their translation in Indonesian translation books tells that sariyyah refers to some youths sent by the Prophet Muhammad PBUH before or during the war. The researcher compared the original Arabic and Indonesian books and found several sariyyah words that were translated, but the dominant one was not translated. According to the researcher observations, the translation of the word sariyyah is not translated because the translator does not know the appropriate equivalent for the word sariyyah even though the equivalent can be made, as evidenced by the results of literature studies in the Comprehensive Security Terms Dictionary and the Arabic-Indonesian Dictionary by Muhammad Yunus. Therefore, the term suggested being the equivalent of sariyyah is Military Operations Apart from War (OMSP).[] 


\section{References}

Administrator. n.d. Definition and meaning of "سرية" in the Whole Dictionary of Meanings. In Arabic-Arabic Lexicon by Almaany.com. Retrieved July 8, 2020, from https://www.almaany.com/ar/dict/ar-ar/ سرية

Baer, Brian James. 2020. "From Cultural Translation to Untranslatability", Alif: Journal of Comparative Poetics, No. 40.

Baalbaki, R. 1995. "Reclassification in Arab Grammatical Theory". Journal of Near Eastern Studies, Vol. 54, No. 1.

Bassylev, V. N. 2008. "Semiotic Translation Model”, Politicheskaya Lingvistika, Vol. 1, No. 24.

Bassnett, S. 1991. Translation Studies. London: Routledge.

Callow, J., \& C, Kathleen. 1982. "Review: Approaches to Translation”, SAGE Journal, Vol. 33, No. 3.

Catford, J. C. 1965. A Linguistic Theory of Translation. Oxford: Oxford Press.

Fahli, M. F. 2018. Nurul Yaqin Sirah Nabi Muhammad Pemimpin Para Rasul. Mekkah: Maktabah Ummul Qura.

Folkart, Barbara. 1991. "Le conflit des énonciations-Traduction et discours rapporté, Montréal, Les Éditions Balzac", Meta: journal des traducteurs/Meta: Translators' Journal, Vol. 38, No. 2.

Hatim, B., \& Mason, I. 1997. The Translator as Communicator. London: Routledge.

Hidayatullah, M. S. 2017. Cakrawala Linguistik Arab. Jakarta: PT Grasindo.

Hidayatullah, M. S. 2017. Jembatan Kata: Seluk-Beluk Penerjemahan Arab-Indonesia. Jakarta: PT Grasindo.

Hoed, B. H. 2006. Penerjemahan dan Kebudayaan. Jakarta: Pustaka Jaya.

Holes, C. 2004. Modern Arabic: Structures, Functions, and Varieties. Georgetown: Georgetown University Press.

al-Khudhari, M. 2010. Nurul Yaqin fi Sirah Sayyidil Mursalin. al-Hadits.

Larson, M. L. 1991. Translation Theory and Practice, Tension, and Interdependence. Amsterdam: John Benjamins Publishing Company.

Louise, Audet. 2009. "Evaluation of Literary Translation: From "Sensitivity to Literariness" to "Literariness in Translation", Journal TTR, Vol. 21, No. 1.

Machali, R. 2000. Pedoman umum bagi Penerjemah. Jakarta: Arcan.

Malmkjaer, K. 2005. Linguistic and the Language of Translation. Edinburgh: Edinburgh Press.

Mujani, Saiful., and Liddle, R. Wiliam. 2009. "Muslim Indonesia's Secular Democracy", Asian Survey, Vol. 49, No. 4.

Muta'ali, A. 2018. Kritik Linguistik Terhadap Terjemah Al-Qur'an Berbahasa Indonesia. Jakarta: Rajawali Press.

Muta'ali, A. 2012. Membangun Negara Kuat: Kontribusi Islam Terhadap Pemikiran Politik Barat. Depok: UI Press. 
Arabi : Journal of Arabic Studies

Myskja, Kjetil. 2013. "Foreignisation and resistance: Lawrence Venuti and his critics", Nordic Journal of English Studies, Vol. 12, No. 2.

Newmark, P. 1988. A Textbook of Translation. Saddle River: Prentice-Hall.

Nida, E. A. \& Taber, C. R. 1974. The Theory and Practice of Translation. London: United Bible Societies.

Owji, Zohre. 2013. "Translation Strategies: A Review and Comparison Theories", Translation Journal, Vol. 17.

Ryding, K. C. 2005. A Reference Grammar of Modern Standard Arabic. Cambridge: Cambridge University Press.

Saldanha, G. \& Sharon, O. 2013. Research Methodologies in Translation Studies. London: Routledge.

Susam-Sarajeva, S. 2009. "The case study research method in translation studies", Interpreter and Translator Trainer, Vol. 3, No. 1.

Syihabuddin. 2004. Teori dan praktik penerjemahan Arab-Indonesia. Jakarta: Departemen Pendidikan dan Kebudayaan.

Venuti, L. 1995. The Translator's Invisibility. London: Routledge.

Wandelt, I. 2009. Kamus Keamanan Komprehensif Indonesia: Akronim dan Singkatan. Jakarta: Friedrich Ebert Stiftung (FES) Indonesia Office.

Yunus, M. n.d. Kamus Arab-Indonesia. Jakarta: Insan Multi Media. 